\title{
Website Quality of the Travel Agencies in Malaysia
}

\author{
Choi Sang Long \\ Faculty of Business, Raffles University Iskandar, Malaysia \\ Joseph Wee-Siong Hii (Corresponding Author) \\ Faculty of Business, Raffles University Iskandar, Malaysia \\ E-mail: josephHII@raffles-university.edu.my
}

Tan Owee Kowang

Faculty of Management, Universiti Teknologi Malaysia, Malaysia

Goh Chin Fei

Faculty of Management, Universiti Teknologi Malaysia, Malaysia

Nor Radhiha Abd Rashid

Faculty of Management, Universiti Teknologi Malaysia, Malaysia

Received: February 23, 2018

doi:10.5296/bms.v9i1.13114
Accepted: March 7, 2018 Published: May 9, 2018

URL: https://doi.org/10.5296/bms.v9i1.13114

\begin{abstract}
This paper examined the website quality of travel agencies in Malaysia. The extended Model of Internet Commerce Adoption (eMICA) is used to measure the research objectives. Travel agencies from Johor, the south most state in Malaysia are chosen as research sample in this study. The findings shows that travel agencies have websites which successfully provide basic information such as telephone number, address, email address, contact person, fax number and travel agency background but lack of reservation information. The majority of
\end{abstract}


travel agencies (82.2\%) that are analysed in this study are at Stage 2.

Keywords: Travel agencies, Website quality, Trust, eMICA, Dimension 


\section{Introduction}

A website is essential for business and important marketing tool for the business. A website also is a 'shop window' that works for 24 hours a day, reaching global markets, promotes the product and services, gives credibility, offers online support to customers where can save time and provides a way for people to contact (Reed, 2011). A website is no longer a one-way channel but it can offer a huge advantage if used to its full potential. Today, when people want to buy something, the web is almost always the first stop on their shopping trip. Travel agency is not excluded where visitors should be able to leave comments, subscribe to articles, download materials, and click to chat (Fawzy and Dworski, 2011).

Before the Internet revolution, customers tend to use traditional travel agency because of their low confidence and trust doing the transaction via Internet especially involved money transfer. Traditional travel agent can provide much more customized information by gathering and organizing information unique to their customers' travel needs. The customer must go to the travel agency during office hour to look at the various catalogues and offers and also enquiring the ideal itinerary for vacation trips (Noboa, 2002). But now, the Internet and Web play a major role for customers to get the information and more humanized, uncomplicated, secure and also offer more customized services. Customer tends to seek travel information and purchase tickets through website (Cheung and Law, 2009).

\subsection{Problem Statement}

The Internet users have increased dramatically in Malaysia which provides a great opportunity for travel agencies to start investing in e-commerce technology. According to Internet World Stat (2017), the statistic stated that at the end of December 2016, almost 24.6 million are Internet users in Malaysia. Malaysia is still new to the experience of exploiting innovation of technology within the travel industry. Therefore, travel agencies should take advantage of this to upgrade its website to be more informative.

According to Suraya (2005), Malaysian travel agencies have been slow to deploy advanced technology and the innovation of the Internet and e-commerce is an opportunity to Malaysia travel agencies to promote their product and services in a global market. Many studies on the ICT adoption of SME in Malaysia conducted, but very little on the study of travel agencies website and it quality. This study aimed to investigate the quality of travel agencies website content and quality. The anticipated outcome of the research was to generate an understanding of the use of the Internet on the tourism industry either Johor travel agencies adopted the innovation of the Internet as a whole or not by looking at the level of website quality (excellent or poor).

The website content is very important for answering what customer wants. Customers tend to be searching their own self for getting some information about their willingness to their asking. According to Heung (2003), information of booking, purchase of travel products and services is most important resource for travellers when they are seeking for the information 
and thus when travel agency fail to provide quality content for their website will create dissatisfaction to their prospect customer.

Hence, for this research, the dimensions of the extended Model of Internet Commerce Adoption (eMICA) model are important criterias to investigate website quality since the model is widely used in the tourism industry studies. The dimensions used a range of features to evaluate the content of hospitality website and email. The success of the website was determined by a set of website dimensions, comprised a number of attributes (Hsu and Law, 2005). Travel agency studies use a dimension to provide not only the current knowledge but also solid foundation for theoretical development (Park, 2007) such as facilities information, customer support, customer contact information, surrounding area information (Zafiropoulos, Vrana and Paschaloudis, 2005; Law and Hsu, 2005), customer relationship management (Hashim and Salawati, 2011) and other dimensions.

Various tourism business sectors applied the dimensions to explain the relationship between characteristic itself. These studies measure the richness of specific and comprehensive information dimensions, which as a whole constitute the information service offered through the web. The result shows strong support on relationship between characteristics itself with dimensions but small use of their websites potential. In addition, a study of international travel agencies found many travel agencies do not develop their own websites and although travel agencies are using the web, they are not fully utilized (Park, 2007). The study on the travel agency's website shows that dimensions very rarely used.

Apart from that, this study applied the extended eMICA model to evaluate the website quality. The extended eMICA model consists of three stages incorporating three levels of business process (Promotion, Provision, and Processing). These stages indicate where a business or industry sector is in its development of internet commerce applications. Previous studies use the eMICA model to evaluate the level of website quality (Kerr, Tsoi and Burgess, 2009) and found that not all website offering Stage 3 functionality (transaction processing). Most of the dimensions and eMICA model has been applied in international countries and there are no studies in Malaysia. This study also used the eMICA model with similar approach to evaluate the travel agency website quality in Malaysia. Therefore, this study would like to address two research questions as below;-

Research Question 1: What is the website features in Southern Malaysia's travel agency?

Research Question 2: What is the stage of the website quality among Southern Malaysia's travel agency?

\section{Literature Review}

\subsection{The Extended Model of Internet Commerce Adoption (eMICA)}

The extended Model of Internet Commerce Adoption (eMICA) (see Table 1) was used widely in tourism sectors (Doolin, Burgess \& Cooper, 2002; Zafiropoulos, Vrana and Paschaloudis, 2005; Lin, Zhou and Guo, 2009; Pesonen and Palo-oja, 2010). This model 
consist of three stages: Stage 1 (Promotion), Stage 2 (Provision) and Stage 3 (Processing). Promotion is the initial stage of web development, with static information which serves mainly to promote and publicize the business offerings while Stage 2 is when the company website moves to a dynamic information system with a web front end. The Stage 3 is an important role for any business website which concerned about the online transaction.

The Model of Internet Commerce Adoption (MICA) originally was developed by Burgess and Cooper (2000) for a study in the Australian metal fabrication industry and has been used by many of researchers. The model proposes that in developing commercial websites, small medium enterprise typically start simply by establishing a presence on the web and build on functionality over time, as their experience with and expertise in the use of Internet technologies increases.

Lin, Zhou, and Guo (2009) evaluated the website quality by using the extended Model of Internet Commerce Adoption (eMICA) model with some modification. The eMICA model has three stages which is Promotion, Provision, and Processing. According to Doolin, Burgess and Cooper (2002), uses interactivity as the primary means of establishing the various stages of Internet commerce adoption and usefulness of distinguishing tourism website depending on the level of interactivity.

The website quality levels will be evaluated by stages in EMICA model whether it is an excellent or poor website (Abou-Shouk and Lim, 2010). Table 1 shows the level of quality where Stage 1 until Stage 2, Layer 2 are classified a low levels of e-commerce practices (poor) and Stage 2, Layer 3 and Stage 3 is considered as advanced practices of e-commerce (excellent).

Table 1. The Level of Website Quality base on eMICA Model

\begin{tabular}{|c|c|c|}
\hline eMICA & Description & Level of Quality \\
\hline Stage 1: Promotion & \multirow{3}{*}{$\begin{array}{l}\text { Company name, physical address and contact } \\
\text { details, area of business. } \\
\text { Annual report, email contact, information on } \\
\text { company activities. }\end{array}$} & \multirow{6}{*}{$\begin{array}{l}\text { Low-level } \\
\text { e-commerce } \\
\text { practices } \\
\text { (Poor) }\end{array}$} \\
\hline $\begin{array}{l}\text { Layer 1: Basic } \\
\text { Information }\end{array}$ & & \\
\hline $\begin{array}{l}\text { Layer 2: Rich } \\
\text { Information }\end{array}$ & & \\
\hline Stage 2: Provision & \multirow[b]{2}{*}{$\begin{array}{l}\text { Basic product catalogue, hyperlinks to further } \\
\text { information, online enquiry form. }\end{array}$} & \\
\hline $\begin{array}{l}\text { Layer 1: Low } \\
\text { interactivity }\end{array}$ & & \\
\hline $\begin{array}{l}\text { Layer 2: Medium } \\
\text { interactivity }\end{array}$ & $\begin{array}{l}\text { Higher-level product catalogues, customer } \\
\text { support, industry specific value added features. }\end{array}$ & \\
\hline $\begin{array}{l}\text { Layer 3: } \\
\text { interactivity }\end{array}$ & $\begin{array}{l}\text { Chat room, discussion forum, multimedia, } \\
\text { newsletters or update by email. }\end{array}$ & \multirow{2}{*}{$\begin{array}{l}\text { Advanced-level } \\
\text { e-commerce } \\
\text { practices }\end{array}$} \\
\hline Stage 3: Processing & Secure online transactions, order status and & \\
\hline
\end{tabular}


tracking, interaction with corporate servers.

(Excellent)

Source: Abou-Shouk and Lim (2010)

\subsection{Previous Studies on Website Evaluation}

Tourism destination on the web today is one of the most powerful set of tools for its marketing and promotional activities (Baggio, Mottironi and Corigliano, 2011). The website is a place where the travel agency can communicate with customers and to facilitate business transaction (Merwe and Bekker, 2003). Many large travel agencies do not develop and maintain their own website and although travel agencies are using the web, they have not yet fully utilized their capabilities (Park, 2007). According to Ozturan and Roney (2004), the result shows that approximately 65 per cent of the travel agencies in the sample have a website but unfortunately the site are not interactive since they convey mostly static information, such as the pre-trip information about the tours offered and visual information. Most of the travel agencies update their website every three months and only a small percentage updates their website weekly.

Zafiropolous and Vrana (2006) studied the presence of Greek hotel websites. In their study, six information dimensions including facilities information, guest contact information, reservation/ price promotion, surrounding area information, management of the website and company profile are evaluated. The result shows reservations and price information, considered to be the most significant dimension, while facilities information concerning the top 25 hotel brands' websites presents very high scores. Guest contact information, reservation/ price information, surrounding area information, and facilities information are the dimensions with the highest provision of information features. The overall quality score for the top 25 hotel brands is about $73 \%$, which should be considered to be very high.

In the second part of their study, Zafiropoulos, Vrana and Paschaloudis (2005) measure the richness of specific and comprehensive information dimensions by using hotel managers' response regarding the importance of the offered information services used. This study applies the conceptual model combining seven data dimensions: facilities, customer contact, reservation and prices, surrounding area information, management of the website, company information and communication. The result showed that the Greek hotels utilize a small percentage of the Internet potential as a whole and provide very little reservation and prices information which could enhance e-Business.

Other than that, this article also describes evaluations of the website. Law and Hsu (2005) performed a study to investigate the perceived importance of dimensions and attributes on hotel websites from the perspectives travellers. Reservation information is the most important dimension and room rates as the most important attribute. The findings of this study indicated that the customers' expectation is high on up-scale hotels including their website quality than on website of lower-scale hotels. Their expectation may also be due to the higher level of risks when making reservation. They need greater information when making purchasing decision on up-scale hotel websites. 
Hashim, Murphy, Hashim M. (2007) stated that there are minimal support to the first and second hypothesis. Kelantan showed little difference from the 14 other DMO (Destination Marketing Organization) homepages in reflecting Islam on its website. Only Kelantan's homepage included Muslim prayer schedules. Compared to Sabah and Sarawak, the DMO's homepages in Peninsular Malaysia had a marginally stronger Islamic focus. Lastly, more Islamic pictographic and narrative imagery was evident during Hari Raya (Malaysian event after fasting month also called Eid ul-Fitr).

Lin, Zhou and Guo (2009) employ the eMICA model to evaluate website quality of travel agency in China with some modifications of the model elements. The findings show that travel agencies in China were not utilizing the Internet to its full potential, particularly in terms of marketing using its websites where the majority of the websites are at Stage 2 and none of the websites have developed to Stage 3.

Kerr, Tsoi and Burgess (2009) also use eMICA model to evaluate the level of website development in Hong Kong tourism where eleven governments and nine private website were selected. The study shows that the majority of Hong Kong tourism websites (business website) had been well-developed with a comprehensive information base and rich functionality. Similar with Burgess, Cooper, Cerpa and Sargent (2005)

Another study content website, Park (2002) analysed data from the top 60 travel agencies websites in Korea that many travel agencies do not develop their own website and although travel agency agencies are using the Web, they have not yet, fully utilized capabilities of the websites. Almost all large travel agencies in Korea ignore the Web-based tourism marketing. While travel agencies are establishing websites, very few agencies on the web are actually considering their sites as selling spaces. Most travel agencies do not consider website as marketing tools for foreigners because only a few have English versions of the website.

According to Alwahaishi, Snasel, and Nehari-Talet (2009), two of the seven airlines stressed on transactional content, passenger's enjoyment and website design followed by informational content. Transactional content such as e-ticket, e-payment, online boarding pass, seat map, ticket online changing, booking options and online channel holds the highest preference which is crucial to the airline website's success. Passenger's loyalty is one of the important issues to develop and maintain by flyer program online, customer queries and feedback, and special offers and deals. This option gives a good relationship with existing and future passengers indirectly. Besides that, it is noticeable that there is a strong positive relationship between the website's design and the overall website quality as the passengers' prime concerns when performing online transactions are security and website's ease of use.

In addition, regarding to Li and Wang (2010), accordingly a website should be evaluated on five dimensions, including information, communication, transaction, relationship and technical merit (ICTRT). Among the four marketing function, most of the items in information dimension were better applied than other dimensions. Web seal certification on the search function scored the highest. The majority of the State Tourism Offices' (STOs') used more 
information features related to activities in their website.

Morosan and Jeong (2008) stated that travellers had more favourable views of intermediary website rather than hotel-owned website. The need for lowest room rates online, easy to use reservation tools, comparison of room rates across properties within a destination, and security of online transaction are priorities to them. The cheap prices and discount will make them come again and at the same time can fulfil their demand.

According to Kim et al (2006), the result shows that each online travel agency had some different patterns based on web features, user friendliness and security, and findings low fares. Most of the people searching the Internet for travel reservations seek bargain airline tickets, hotel rooms, car rental, vacation and cruise packages. Furthermore, people search for price information from more than one online travel agency to compare the prices. It happens because different online travel agencies could offer similar product and services but with widely different prices. User-friendly website and ease in navigation helped people to find the information properly.

\section{Research Method}

\subsection{Research Design}

There were two types of sources which are primary data and secondary data used in this research. For this research, collecting data method is used to identify different information and source.

\subsubsection{Primary Data}

Primary data is data has not been previously published and the information is obtained directly from first-hand source by means of surveys, questionnaires, interviews, observation, or experimentation. Primary data is the data originated by the researcher for the specific purpose of addressing the research problem (Burns and Bush, 2012). Primary data in this research were obtained by analysing website content of travel agencies. The advantages of collecting primary data are focused on the specific issues, to determine the type of methods that were used in collecting the data, and the researchers will be presented with original and unbiased data.

\subsubsection{Secondary Data}

The secondary data is the data that have already been collected by and readily available from other resources. According to Burns and Bush (2012), secondary data have previously been gathered by someone other than researcher and/or for some other purpose than the research project at hand. In addition, Vartanian (2011) has proposed that secondary data can include any data that are examined to answer the research question other than the question (s) for which the data were initially collected. For this research, sources of the secondary data also included the books, journals and Internet. 


\subsection{Research Instrument}

This study uses the eMICA model to evaluate the travel agency website of Johor, because the model has been tested and used on tourism industry (Lin et al., 2009). Each features in eMICA model come from the combination of previous article where some of the features are omitted and some of them are added. The purpose of this combination is to get a variety of findings regarding the independent variables. The eMICA model consists of three stages, incorporating three levels of business process. First stage is web-based promotion, second stage is provision of information and services, and last stage is processing. Each stage has a few layers that indicate the level of development of Internet commerce application for each website. In order to measure the level of development, eMICA incorporates a number of additional layers of complexity, ranging from very simple to highly sophisticated, within the identified main stages of the model.

\subsection{Location of the Study}

The study analysed the travel agency's website content in Johor Bahru area to measure the affectiveness of website content. There are 268 travel agencies in Johor and all the travel agency websites were obtained from the Tourism Malaysia official website in 2012 (www.tourism.gov.my/) where the website provides the information about Malaysia such as tourism directory, travel packages, destinations, accommodations/ where to stay, travel agents and events \& festivals.

\subsection{Population and Sample Selection}

The population was census on 268 Johor travel agencies registered with Malaysia Tourism 2013. The travel agencies were divided into two types of organization (with and without branch). During the evaluation process, out of 268 travel agencies, 203 websites were not found and only 65 travel agencies have websites. All the website addresses were obtained by searching through Google and Malaysia Yahoo!. Out of 65 websites, 15 websites did not work, 5 websites were found under construction and 45 websites are successfully checked.

\subsection{Data Collection and Analysis}

This study uses content analysis to investigate the presence of website features. Tourism Malaysia did not provide website address. Search engines (Mozilla Firefox, Internet Explorer, Opera and Chrome), Google and Yahoo! were used to find the corresponding websites. For getting the address of travel agency website, one need to key-in each travel agency's name into Google and Yahoo! The site quality maybe influenced by the type of browser, computer speed, Internet speed and time of the day and these external factors were in controlled when conducting the content analysis of the site. This study used the same browser, high speed Internet connection, same Pentium computer, and slot of the day.

This study uses the coding sheet during content analysis to make sure all the features is are analysed properly. Coding sheet development consisted of a review of the relevant academic and practitioner literature and in-depth analysis of randomly selected travel agency websites 
(Park, 2007).

The data collection for this research was obtained through the website content analysis of travel agencies in Johor. Data collection proceeded in two stages in the month of September and November, 2012. The first step is to identify the status of those travel agencies that did and did not maintain websites. Two search engines (Google and Yahoo! Malaysia) as well as direct connection (using www.tourism.gov.my) were used to locate each travel agency's homepage and used to find the corresponding websites. The homepage address (the URL) of each identified site was recorded. Based on Tourism Malaysia official website, there are 3,511 travel agencies in Malaysia by 2012. There are over 268 travel agencies in Johor in the year of 2012.

Website content analysis depends on external factors such as type of browser, computer speed, Internet speed, and time of the day (Lin, Zhou and Guo, 2009). The travel agencies identified as maintaining websites in the first stage proceeded to the second stage of data collection. The second stage is to code every website features to coding sheets. Coding sheet has been used for filling the data for each travel agency's website. Coding sheet development is a review of the relevant academic and practitioner literature (Park, 2007).

\section{Findings}

\subsection{Data Collection}

Data was collected by using content analysis to evaluate the presence of website features on Johor travel agencies. Similar with Park (2007), a content analysis is used to accomplish the purpose of the study. There are 268 of travel agencies in Johor and some of the travel agencies did not have an official website. In each of the coding sheet, there are three sections which followed the eMICA model format - Stage 1, Stage 2 and Stage 3 (see Table 3.6) derived from previous research by Park (2007), Kerr, Tsoi and Burgess (2009), Pesonen and Palo-Oja (2010) and Abou-Shouk and Lim (2010). All travel agency's website has been explored on each element and marked on the coding sheet. All the travel agency websites features collected were keyed into a data matrix for analyst.

\subsection{Data Analysis}

This part is about the data analysis where the process of finding the right data to answer the research questions. It consists of descriptive analysis and chi-square analysis. This research used four dimensions (Process, Web-based marketing, Trust and Customer support) and applied all the dimensions to eMICA model to evaluate the stages of website quality. 
4.2.1 Descriptive Analysis

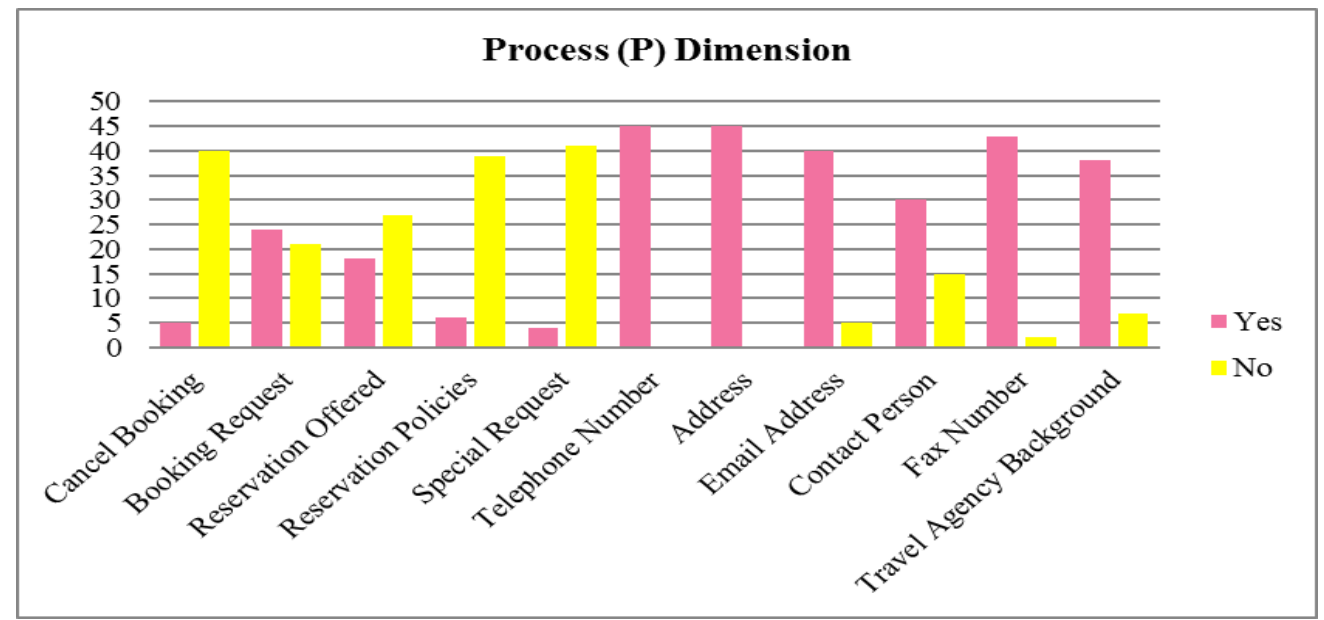

Figure 1. Numbers of Features in Process Dimension

The Figure 1 above shows the descriptive statistic for the Southern Malaysia's travel agency. Telephone number and address are the two features that all Johor travel agencies provide followed by fax number (43 of 45), email address (40 of 45), travel agency background (38 of 45) and contact person (30 of 45). Most of the travel agencies did not provide special request form (41 of 45), reservation policies (39 of 45) and cancel booking (40 of 45). Here, most of the travel agencies fulfil the requirements for containing basic corporate information.

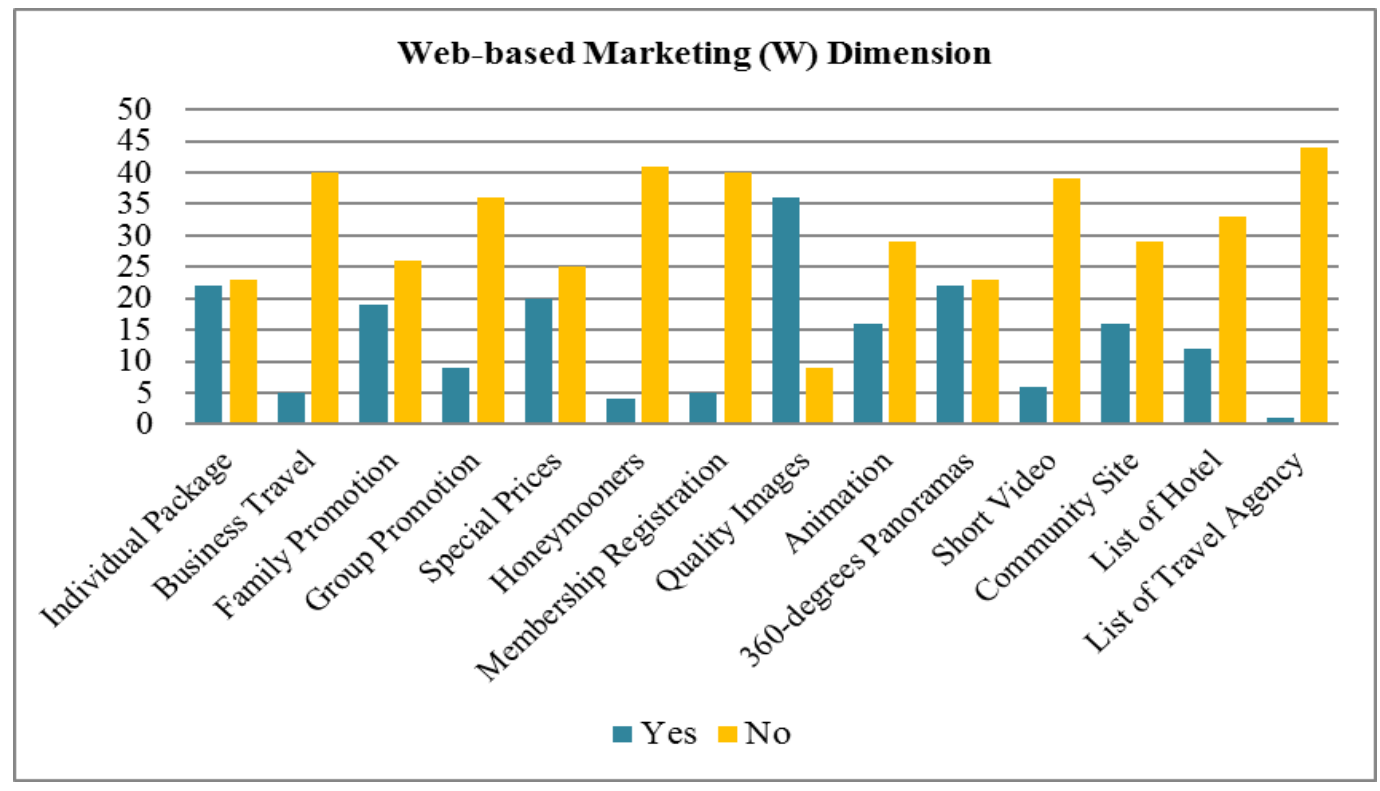

Figure 2. Numbers of Features in Web-based Marketing Dimension

For the second dimension, Figure 2 shows the descriptive statistics for the Web-based marketing dimension features. Most of the Johor travel agencies provided quality image (36 of 45) followed by 360-degrees panoramas (23 of 45) and individual package promotion (22 of 45). However, forty-four of the travel agencies did not provide a list of travel agencies in their website followed by honeymooner's package (41 of 45), business travel promotion (40 
of 45), membership registration (40 of 45) and short video (39 of 45). Only one travel agency provided a list of travel agencies compared with the others.

According to Park (2007), web-based marketing among Korean travel agencies are also weak and just at an initial stage. From the statistical result, travel agencies in Johor mostly did not stressed on their promotional package and entertainment resources in their website. Different with Pesonen and Palo-oja (2010), stated that the number of high interactivity feature for the Finnish and the European companies is quite low except for the use of multimedia. Here, multimedia resource plays an important role for giving reviews of destination and attracting people to choose their right destinations.

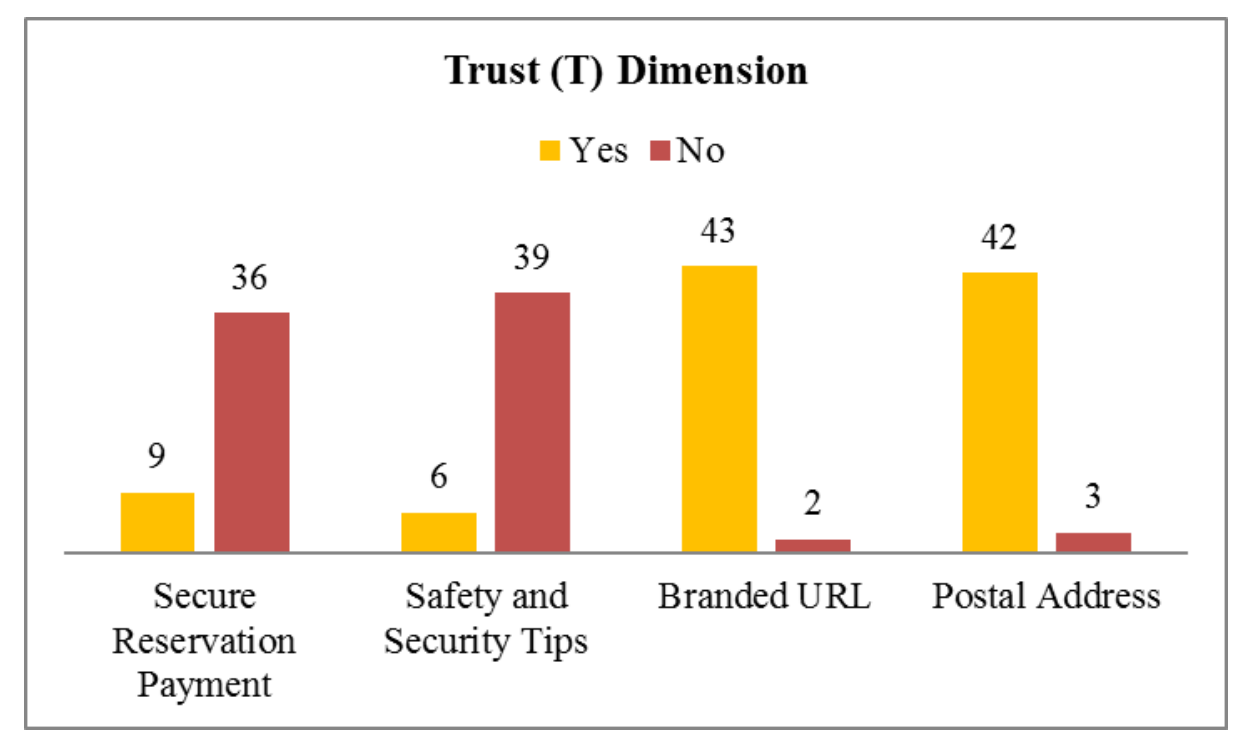

Figure 3. Numbers of Features in Trust Dimension

The Figure 3 above shows the descriptive statistics for Trust dimension features. The result shows that most of the travel agencies are not really good at providing trust features to their website. This is especially seen in secure reservation payment and safety and security tips. It is recorded at 9 and 6 on the website respectively as compared with branded URL, which recorded a high number which is 43 websites followed by postal address (42 of 45). The result are supported by Park (2007), Lin, Zhou and Guo (2009), and Ker, Tsoi and Burgess (2009). 


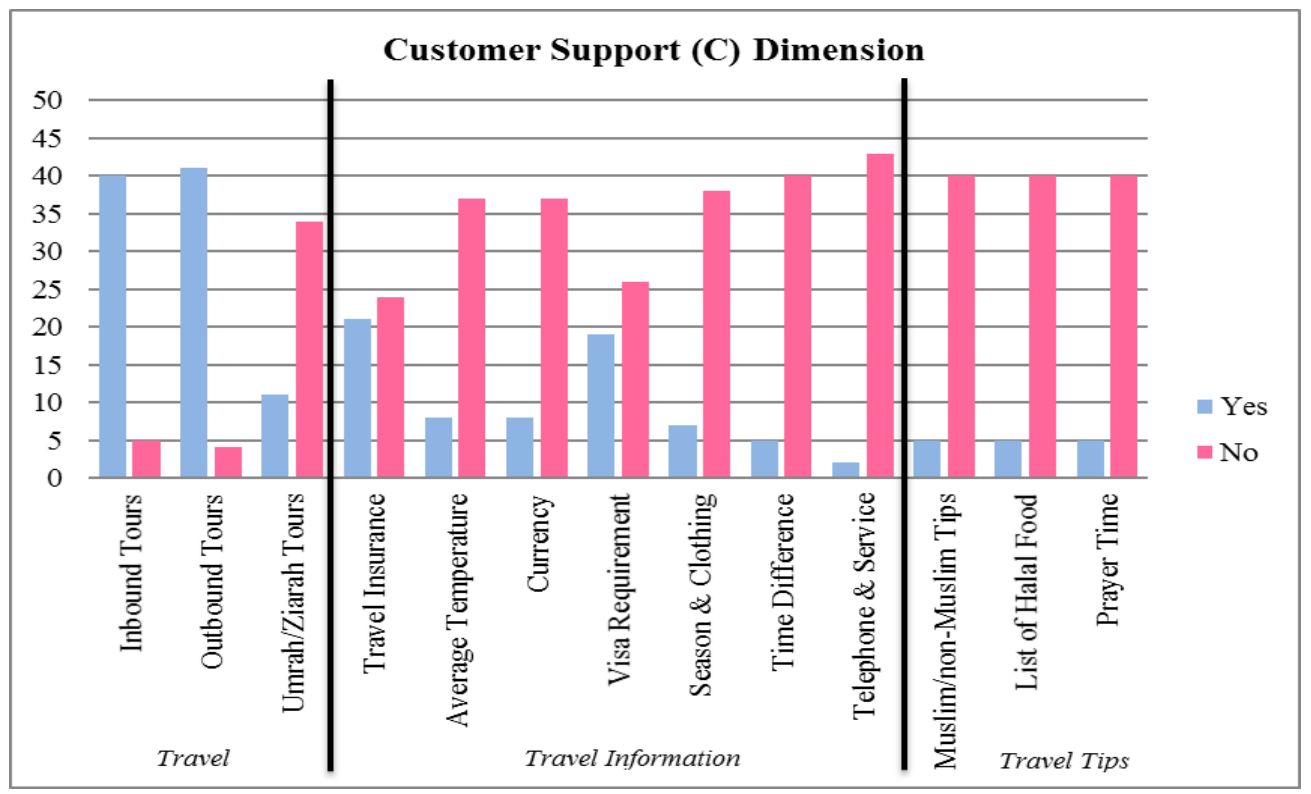

Figure 4. Numbers of Features in Customer Support Dimension

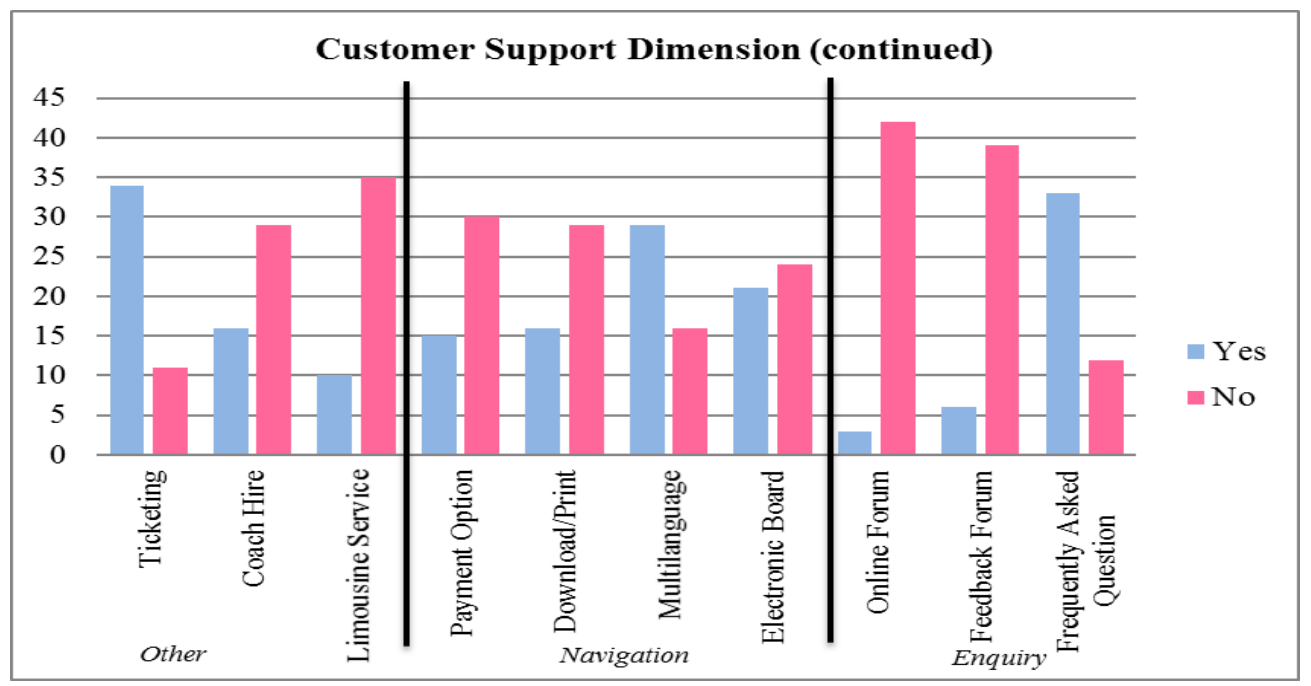

Figure 5. Numbers of Features in Customer Support Dimension (continued)

Figure 4 and Figure 5 shows the descriptive statistic for Customer Support dimension features consisting of six elements: travel package, travel information, travel tips, other services, navigation and enquiry. For travel packages, outbound tours features are the highest number with forty-one travel agencies provided in their website followed by inbound tours (40 of 45). Twenty-three of the travel agencies provide travel insurance features and nineteen ef travel agencies presence visa requirements in the website respectively. These two features are the highest ranking in travel information as compared with telephone and services and time difference, each with recordings of forty-three and forty travel agencies which were not provided in their website. In addition, only five travel agencies provide travel tips for Muslim and non-Muslim, list of halal food's outlets and prayer time to their website.

Furthermore, for other services, the highest number was recorded with thirty-four ef travel 
agencies provideing ticketing features and thirty-five of the travel agencies did not provide limousine service to their websites. For navigation, most of the travel agencies provide multilanguage (29 of 45) and thirty of the travel agencies failed to provide payment option features. Half of the travel agencies considered website as marketing tools for foreigners and locals because of providing multilanguage in their website. Different with Park (2007), that most of the Korean travel agencies have less English version. Besides, thirty-three of the travel agencies are quite good with providing frequently asked question as compared with online forum where only 3 travel agencies managed to provide. Overall most of the Johor travel agencies are good in providing inbound tours, outbound tours, and ticketing feature on their website but not good in providing telephone and service, travel tips and online forum respectively.

For the second objective it is aimed to evaluate the stages of website quality among the Southern Malaysia's travel agency. The results of the study are shown in Table 2. From the statistical result, majority of the Johor travel agencies' website exhibited features which are in consistent with Stage 2 of eMICA. Site developed at this stage providing interactive and value-added features characterised by level of interactivity and features with three levels of Stage 2: Low, medium and high interactivity.

Table 2. Results of the Travel Agency Website Evaluated

\begin{tabular}{|l|l|l|}
\hline Stage of eMICA & Number of Website & Percentage of Total Websites \\
\hline Stage 1: Layer 1 & 3 & $6.7 \%$ \\
\hline Stage 1: Layer 2 & 0 & $0.0 \%$ \\
\hline Stage 2: Layer 1 & 5 & $11.1 \%$ \\
\hline Stage 2: Layer 2 & 20 & $44.4 \%$ \\
\hline Stage 2: Layer 3 & 12 & $26.7 \%$ \\
\hline Stage 3 & 5 & $11.1 \%$ \\
\hline Total & $\mathbf{4 5}$ & $\mathbf{1 0 0 \%}$ \\
\hline
\end{tabular}

All the Johor travel agencies had been well developed with a comprehensive information base and rich in functionality. This shows that all travel agencies in Johor successfully presence basic information at Stage 1. The main difference among Johor travel agencies website is in Stage 2 (Provision). The majority of the websites (82.2\%) exhibited features consistent at Stage 2 of eMICA. As shown in Table 2, the level of interactivity is very high at the Stage 2, Layer 2 with twenty travel agencies followed by Stage 2, Layer 3 (twelve travel agencies) and five travel agencies at Stage 2, Layer 1 but gradually gets lower until Stage 3 where only five travel agencies provide online transactions. These results are supported by Lin, Zhou and Guo (2009), in the highest number of websites is at Stage 2 and the second is at Stage 1 where customers can find information internal and external websites quickly and easily.

Table 3. The Level of Website Quality based eMICA model

\begin{tabular}{|l|l|l|}
\hline Stage of eMICA & $\begin{array}{l}\text { Number of Website } \\
\text { N (\%) }\end{array}$ & Level of Website Quality \\
\hline Stage 1: Layer 1 & $3(6.7)$ & \\
\hline
\end{tabular}




\begin{tabular}{|l|l|l|}
\hline Stage 1: Layer 2 & $0(0)$ & $\begin{array}{l}\text { Low-level e-Commerce } \\
\text { Practices (POOR) }\end{array}$ \\
\cline { 1 - 2 } Stage 2: Layer 1 & $5(11.1)$ & \\
\hline Stage 2: Layer 2 & $20(44.4)$ & High-level e-Commerce \\
Stage 2: Layer 3 & $12(26.7)$ & Practices (EXCELLENT) \\
\hline Stage 3 & $5(11.1)$ & \\
\hline Total & $45(100)$ & \\
\hline
\end{tabular}

As shown in Table 3, it was found that there are 17 travel agencies with an excellent website quality and 28 travel agencies are categorised as poor website quality. Most of the websites beyond Stage 2, Layer 2 indicated the websites are stressed on interactive online presence as compared with other 8 websites. This study classified in the Stage 2, layer 2 does not necessarily have 50 percent or more features in Stage 1 but if the website adopted less than 50 percent at Stage 1 and adopts 50 percent and more at Stage 2, it could be as Stage 2, Layer 2. This approach is same with eMICA model result. Findings indicated that only 17 out of 45 websites is at Stage 2, Layer 3 and Stage 3. High interactivity and processing functionality are classified as advanced-level e-commerce practices (Excellent website quality). This level stressed on electronic transactions, travel tips, enquiry, reservation (cancel booking, booking request, reservation offered, reservation policies, and special request form), privacy statement (secure reservation payment, safety and security tips), and branded email address. For this level, the websites offering secure online credit card payments for accommodations and travel bookings which increases customers' confidence level to do online purchases.

\section{Discussion}

Research Question 1: What is the website features in Southern Malaysia's travel agency?

From the results of this study, there are 76 percent of travel agencies in Johor that did not have a website. Creating a website presence is very expensive and complicated. Thus, travel agencies have to spend huge costs to build an excellent website and also hired a worker that can manage the functionality of the website. For those that have a website, the a content analysis of travel agencies' website shows that main travel agencies do not develop and maintain their own website and although travel agencies having thre websites, they do not utilize it as much as possible as an informative website and these finding has been proven by Park (2007). Travel agencies that have a website successfully providing basic information such as telephone number, address, email address, contact person, fax number and travel agency background but lack of reservation information (cancel booking, reservation policies and special request).

These findings are also supported by Roney and Ozturan (2006), travel agencies in Turkey successful exhibited basic information but brief history of the company and name of contact person is not revealed. Travel agencies should provide reservation information effectively in their website for the convenience of users. For example, if customers are unable to travel on the dates specified on a ticket, it is utmost important for them to cancel their booking and make new arrangements for alternative travel. This application should be one of the main website content and this has proved its effectiveness by Kim, Kim and Han (2007). The 
findings shows booking request and reservation offered as the most and second most features that website presence whereas cancel booking, reservation policies and request number least features presence. These findings are supported by Law and Hsu (2005) as reservation information is the most important dimension for e-traveller and managers.

Multimedia resources are also a crucial part to encourage customers to make their purchase online. Travel agencies should stress on this functionality. The attractions, enjoyment and entertainment via short video, quality images, animation and 360-degrees panoramas is important to provide a tangible sense of place (Buhalis and Law, 2008). In addition, customers will be able to see and feel the scenery destinations offered before choosing the right destination. This matched the statement made by prior studies that a few websites made use of multimedia (Meintjes, Struweg and Petzer, 2011).

Other than that, trust dimensions also a crucial part in developing a website. In the literature review, there are many definitions in different contexts and situations. Trust is important for enhancing the perception of trust on the Internet and users are concerned with this functionality before they make any online purchase transaction. According to Aljazzaf, Perry and Capretz (2010), trust is the willingness of the trustor to rely on a trustee to do what is promised in a given context, irrespective of the ability to monitor or control the trustee and even though negative consequences may occur. In addition, trust should include the concepts of dependency, confidence expectation, vulnerability, reliability, comfort, utility, context-specificity, risk attitude and lack of control. This study is in line with Murphy, Olaru, Schegg and Prey (2003), trust dimension such as branded URL and postal address have the highest trust element in the web page with 95.6 percent and 93.3 percent respectively= as compared with secure reservation payment and safety and security tips, travel agencies are not readily provided in their website. In the world of search engine and marketing, branding a URL is important for any company. Almost all the Johor travel agencies website have their branded URL and postal address because of a high level of awareness of a company brand and the dangers of being too heavily optimized for their online brand presence.

Most of the travel agencies failed to provide travel tips, online forum, feedback forum, telephone and service information and time difference information. Website should focus on information about the travel packages offered by the agency covering all the needs of travellers before they decide to travel. Travel information provide extensive information for consumers to find the details and the consumers get an overview of the destination to be visited and also the preparation they need to do before travelling indirectly. Information such as travel package will help consumers make a difference in price and service offered.

Apart from that, consumers also can check an itinerary such as the date of departure, the price, other fees applicable, the place to be visited and the schedule of activity has been arranged by the travel agency. Customer will be clear with the information given and may encourage them to plan for the next tour indirectly. Almost half of the travel agencies did not provide travel insurance and visa requirement to the consumers and it will have some impact on the business in which the average consumers would prefer a pretty complete service. If it 
happens, it will encourage them to switch to other travel agency.

Research Question 2: What is the stage of the website quality among Southern Malaysia's travel agency?

Each of the website was investigated and categorized with regards to their level of interactivity. It was found that, Johor travel agencies' website had been well-developed with comprehensive basic information but the difference between travel agency websites begin arising when the first layer of the second stage is examined. The majority of travel agency are at Stage 2 with 82.2 percent and this finding in line with Lin, Zhou and Guo (2009). The level of interactivity exhibited on the sites developed to Stage 2 considerably across the three levels: low level interactivity, medium level interactivity and high interactivity. This interactivity ranged from basic to high level value added features. Twenty-two of the travel agencies are good in exhibiting customer support, value added features and high-level product catalogue. This result matched the prior studies stated that majority of website are ranged at Stage 2 (Ting et al. 2013; Lin et al. 2009; Kerr et al. 2009; Larson and Ankomah, 2008; Burgess et al. 2005 and Doolin et al. 2002) and it is in line with travellers perspective where they felt customer support, value added features and product catalogue should be available on the website (Benchkendorff, 2009).

The first layer at Stage 2 had some form of navigation such as hyperlinks. They had numerous links to further information such as a list of hotels and a list of travel agencies coupled with value added features such as payment option, download and print document, multilanguage, electronic board, quality images, animation, 360-degree panoramas and short video. At Layer 2 of Stage 2, the value added features became increasingly interactive that included special online promotion, membership registration and community site. Special online promotion is an extensive package offered by travel agency to promote their package in a special price. It is one way travel agencies can do their marketing to attract more consumers to subscribe to packages offered. Unlike for this study, business travel, group promotion and honeymooners are less presence in a website.

The number of high interactivity features at Layer 3 of Stage 2 is becoming low. Almost half of the websites did not do well in providing enquiry, travel tips, reservation and other service information. The last stage of eMICA is Stage 3 where only five websites successfully exhibited privacy statement and branded email address. Compared with Kerr, Tsoi and Burgess (2009), business website had been developed at Stage 3. However, Lin, Zhou and Guo (2009) stated that none of the website has developed at Stage 3. Many accommodation travel agency websites offer travel package information and about half of the website offers reservation information for consumers to pay purchase online. Different with Zafiropoulos, Vrana and Paschaloudis (2005), the result shows very little reservation and price information presence in the Greek hotel websites. Almost all travel agencies displayed the reservation information in their websites because they are aware of the consumers' convenience to do online payments. The Johor travel agencies provide more to their consumer navigation and travel information. The high proportion using entertainment and multimedia resources have 
been identified with quality image, animation and 360-degree panoramas. This finding was congruent with Pesonen and Palo-oja (2010) where flash-animation is used widely in a company website.

\subsection{Implication for Findings}

The following implications were drawn from the findings. First, the study found that the content of information in the website should be improved to make an informative website. Even in the Johor travel agency successful displays basic information, there are some elements that should be emphasized which are reservation information that the travel agency have to stress on. Some travel agencies are providing reservation requests but unfortunately some did not provide cancellation. This will cause the consumers difficulty to cancel reservations made and they had to go to the travel agency personally to deal or call the travel agency.

Johor travel agencies should focus more in Trust dimension where secure reservation payment and safety and security tips information must have in every websites. Security is an important issue for secure online payment. The travel agency should make sure that their website provides the security tips and secure reservation payment information and also well equipped with security software to provide certified site and all data transmitted over the browser is encrypted. This information is a crucial part to ensure customers make an online payment with a full sense of security and does not wobble. Despite the fact that 14 percent of respondents believe that booking online is not secure (Bogdanovych, Berger, Simoff and Sierra, 2006), protecting customers' credit or debit card data from being hacked and credit card number being stolen by cyber thieves should be taken seriously.

Thirdly, a website should be maintained and updated to keep consumers returning and ranking highly on the search engine. Most of the Johor travel agencies are so concerned about technology and design but they totally forget that helpful content is the most important aspect of any website. Furthermore, consumers will be able to leave comments, subscribe online catalogue, download and print documents and join a forum chat as long as a site is interactive and updated.

\subsection{Suggestions for Future Research}

Limitation of the study was the relatively small sample size. For this study, only 45 Johor travel agencies' website have been successfully found and for this reason, these findings cannot be generalized to the broader aspects and have profound effects on the outcomes of the study. The results will look different compared with larger samples. The sample for future research should cover all the travel agencies in Malaysia to obtain results that are more compact and accurate.

There are several limitations in this study, but the website evaluation is still being reviewed from time to time either using content analysis or the eMICA model. The number of website for this study is relatively small and need more samples for future research. Therefore, a 
future research should try to gauge the effects of a small sample size before sampling in order to determine whether the small sample size will have a great negative impact on the study's result before getting underway. This study is only to evaluate the travel agency website quality in Johor and suggest that future research will cover all the travel agencies in Malaysia.

\section{References}

Abou-Shouk, M., \& Lim, W. M. (2010). Egyptian Travel Agents and e-Commerce. Information and Communication Technologies in Tourism, 2010, 357-368. https://doi.org/10.1007/978=3=211=99407-8_30

Aljazzaf, Z., Perry, M., \& Capretz, M. A. M. (2017). Online Trust: Definition and Principles. The Fifth International Multi-Conference on Computing in the Global Information Technology (ICCGI 2010), Valencia, Spain. 20-25. https://doi.org/10.1109/ICCGI.2010.17

Alwahaishi, S., Snasel, V., \& Nehari-Talet, A. (2009). Website Evaluation an Empirical Study of Arabian Gulf Airlines. International Journal of Information Studies, 1(3). https://doi.org/10.1109/ICADIWT.2009.5273863

Baggio, R., Mottironi, C., \& Antonioli Corigliano, M. (2011). Technological aspects of public tourism communication in Italy. Journal of Hospitality and Tourism Technology, 2(2), 96-104.

Benckendorff, P. (2006). An Exploratory Analysis of Traveler Preferences for Airline Website Content. Information Technology and Toursim, 8, 149-159. https://doi.org/10.3727/109830506778690867

Bogdanovych, A., Berger, H., Simoff, S., \& Sierra, C. (2006). Travel Agents vs. Online Booking: Tackling the Shortcomings of Nowadays Online Tourism Portals. 13th International Conference on Information Technologies in Tourism- ENTER, 2006, 418-428. http://doi.org/10.1007/3-211-32710-X_55

Buhalis, D. and Law, R. (2008). Progress in information technology and tourism management: 20 years on and 10 years after the Internet-The state of eTourism Research. Tourism Management, 29, 609-623. https://doi.org/10.1016/j.tourman.2008.01.005

Burgess, L., \& Cooper, J (2000). Extending the Viability of MICA (Model of Internet Commerce Adoption) as a Metric for Explaining the Process of Business Adoption of Internet Commerce. International Conference on Telecommunications and Electronic Commerce. https://doi.org/10.4236/jssm.2009.23021

Burgess, L., Cooper, J., Alcock, C., \& Uppala, P. (2004). A Longitudinal Study of the Use of the Web by Regional Tourism Organisations in the Asia Pacific. ACIS 2004 Proceedings. Paper $5 . \quad$ Retrieved from https://pdfs.semanticscholar.org/c2f6/b126ce1f0452c80716dfc486f0293df792ac.pdf

Burgess, L., Cooper, J., Cerpa, N., \& Sargent, J. (2005). A Comparative Analysis of the Use 
of the Web for Destination Marketing by Regional Tourism Organizations in Chile and the Asia Pacific. CollECTeR, $2005 . \quad$ Sydney, NSW. https://doi.org/10.1007/978-0-387-35692-1_36

Burns, A. C., \& Bush, R. F. (2012). Basic Marketing Research Using Microsoft Excel Data Analysis. 3rd ed. Upper Saddle River, N. J.: Prentice Hall. 2012.

Cheung, R., \& Law, P. (2009). How Travel Agency Survive in e-Business World? Communication of the IBIMA, 10, 1943-7765.

Cunliffe, D. (2000). Developing Usable Web sites - A Review and Model. Internet Research, 10(4), 295-308. https://doi.org/10.1108/10662240010342577.

Doolin, B., Burgess, L., \& Cooper, J. (2002). Evaluating the Use of the Web for Tourism Marketing: A Case Study from New Zealand. Tourism Management, 23(5), 557-561. https://doi.org/10.1016/S0261-5177(02)00014-6.

Fawzy, L., \& Dworski, L. (2011). Emerging Business Online: Global Markets and the Power of B2B Internet Marketing. Upper Saddle River, N.J.: Pearson Education.

Hashim, N. H. (2008). Diffusion Of Innovations: Adoption And Use Of Websites And Email Among Malaysian Hotels. Application and Issues in E-Business, 39-56.

Hashim, N. H., Murphy, J., \& Hashim, N. M. (2007). Islam and Online Imagery on Malaysian Tourist Destination Websites. Journal of Computer-Mediated Communication, 12(2007), 1082-1102. International Communication Association. https://doi.org/10.1111/j.1083-6103.2007.00364.x

Heung, V. C. S. (2003). Internet Usage by International Travellers: Reason and Barriers. International Journal of Contemporary Hospitality Management, 15(7), 370-378. https://doi.org/10.1108/09596110310496015

Internet World Stats Usage and Population Statistics (2017). Retrieved from https://www.internetworldstats.com/asia.htm. (December 12, 2017)

Kamarudin, L. M., \& Ismail, H. N. (2012). Muslim Tourists' Typology in Malaysia: Perspectives and Challenges. Proceedings of the Tourism and Hospitality International Conference.

Kerr, G., Tsoi, C. F., \& Burgess, L. (2009). Evaluating the Use of the Web for Tourism Marketing in Hong Kong. Faculty of Commerce- Papers, (2009), 1-8.

Kim, D. J., Kim, W. G., \& Han, J. S (2006). A Perceptual Mapping of Online Travel Agencies and Preference Atrributes. Tourism Mangement, 28(2007), 591-603. https://doi.org/10.1016/j.tourman.2006.04.022.

Larson, T., \& Ankomah, P. (2004). Evaluating Tourism Web Site Complexity. The Case of International Tourism in the U. S., Service Marketing Quarterly, 26(2), 23-37. 
https://doi.org/10.1300/J396v26n02_02.

Law, R., \& Hsu, C. H. C. (2005). Customers' Perceptions on the Importance of Hotel Website Dimensions and Attributes. International Journal of Contemporary Hospitality Management, 17(6), 493-503. https://doi.org/10.1108/09596110510612130.

Law, R., \& Hsu, C. H. C. (2006). Importance of Hotel Website Dimensions and Attributes: Perceptions of Online Browsers and Online Purchasers. Journal of Hospitality and Tourism Research, 30(3), 295-311. https://doi.org/10.1177/1096348006287161.

Lee, G., Cai, L. A., \& O’Leary. J. T. (2006). WWW.Branding.States.US:An analysis of brand-building elements in the US state tourism websites. Tourism Management, 27(5), 815-828. https://doi.org/10.1016/j.tourman.2005.05.016

Li, X., \& Wang, Y. (2011). Measuring the Effectiveness of US Official State Tourism Websites. Journal of Vacation Marketing, 17(4), 287-302. https://doi.org/10.1177/1356766711423436.

Lin, D., Zhou, Z., \& Guo, X. (2009). A Study of the Website Quality of Travel Agencies Based on the EMICA Model. Journal Service Science and Management, 3, 181-185. https://doi.org/10.4236/jssm.2009.23021.

Meintjes, C., Struweg, I. N., \& Petzer, D. (2011). Evaluating Web Marketing of Luxury Lodges in South Africa. African Journal of Marketing Management, 3(9), 233-240.

Merwe, R., \& Bekker, J. (2003). A Framework and Methodology for Evaluating e-Commerce Web Sites. Internet Research: Electronic Networking Applications and Policy, 13(5), 330-341. https://doi.org/10.1108/10662240310501612

Morosan, C., \& Jeong, M. (2008). Users' perceptions of two types of hotel reservation Web sites. International Journal of Hospitality Management, 27(2008), 284-292. https://doi.org/10.1016/j.ijhm.2007.07.023

Murphy, J., Olaru, D., Schegg, R., \& Frey, S. (2003). The Bandwagon Effect: Swiss Hotels' Website and E-mail Management. Cornell Hotel and Restaurant Administration Quarterly, 44(1), 71. https://doi.org/10.1016/S0010-8804(03)90048-6

Noboa, F. (2002). The Internet, The Big Opportunity for Tradiotional Travel Agencies. Retrieved from http://www.iese.edu/cat/files/The\%20internet,\%20the\%20big\%20opportunity\%20for\%20trad itional\%20travel\%20agencies_tcm6-5772.pdf

Ozturan, M., \& Roney, S. A. (2004). Internet use among travel agencies in Turkey: an exploratory study. Tourism Management, 25(2004), 259-266. https://doi.org/10.1016/S0261-5177(03)00097-9

Park, C. (2007). A Content Analysis of Travel Agency Websites in Korea. Asia Pacific. Journal of Tourism Research, 7(1), 11-18. https://doi.org/10.1080/10941660208722105 
Pesonen, J., \& Palo-oja, O. (2010). Comparing Internet Commerce Adoption between the Finnish and the European Independent Accommodation Companies. Information and Communication Technologies in Tourism, (2010), 51-62. https://doi.org/10.1007/978-3-211-99407-8_5

PhoCusWright (2012). PhoCusWright's U.S. Corporate Travel Report: Market Size and Technology Trends 2012.

Reed, J. (2011). Get Up to Speed with Online Marketing: How to Use Websites, Blogs, Social Networking and Much More. FT Press, 264.

Roney, S. A., \& Ozturan, M. (2006). A Content Analysis of the Web Sites of Turkish Travel Agencies. An International Journal of Tourism and Hospitality Research, 17(1), 43-54. https://doi.org/10.1080/13032917.2006.9687026

Salavati, S., \& Hashim, N. H. (2011). An Investigation on Website Adoption and Quality of Iranian Hotel. Second International Conference on Business and Economic Research (2 ${ }^{\text {nd }}$ ICBER 2011) Proceeding. https://doi.org/10.1016.j.tourman.2014.07.017

Suraya, R. M. Y. (2005). Culture and Acceptance Usage of e-Business: Is there a Dilemma?. Proceedings of the International Conference on Electronic Commerce, 102-108.

Ting, P. H., Wang, S. T., Bau, D. Y., \& Chiang, M. L. (2013). Website Evaluation of the Top 100 Hotels Using Advanced Content Analysis and eMICA Model. Cornell Hospitality Quarterly, 1-10. https://doi.org/10.1177/193896551247892

$\begin{array}{llll}\text { Tourism } & \text { Malaysia } & \text { (2012). } & \text { Retrieved }\end{array}$ http://www.tourism.gov.my/ms-MY/Master/Web-Page/About-Malaysia on 1 August 2012.

Vartanian, P. T. (2011). Secondary Data Analysis. Madison Avenue, N. Y.: Oxford University Press, Inc. 2011

Zafiropoulos, C. and Vrana, V. (2006). A Framework for the Evaluation of Hotel Websites: The Case of Greece. Information Technology and Tourism, 8, 239-254. https://doi.org/10.3727/109830506778690812

Zafiropoulos, C., Vrana, V., \& Paschaloudis, D. (2005). An Evaluation of the Quality of Hotel Websites using the Managers' Views about Online Information Service. ECIS 2005 Proceedings. Paper 21. Retrieved from https://aisel.aisnet.org/ecis2005/21

\section{Copyright}

Copyright for this article is retained by the author(s), with first publication rights granted to the journal.

This is an open-access article distributed under the terms and conditions of the Creative Commons Attribution license (http://creativecommons.org/licenses/by/4.0/). 